\title{
ARCHITECTURE AND PHILOSOPHY: PARADOXES AND METAMORPHOSES OF THEIR MEETING
}

\section{A B S T R A C T}

It is well known that Jacques Derrida emphasized the idea of an essential cohabitation between philosophy and architecture, declaring: "The Collège international de philosophie should provide the place for a meeting (rencontre), a thinking meeting, between philosophy and architecture. Not in order to finally have them confront each other, but to think what has always maintained them together in the most essential of cohabitations." This paper addresses in particular a hypothesis about the metamorphoses of this meeting that, from unity of architectonics and principles, becomes multiple and of another nature. So there is a reevaluation in terms of limits and passages; in other words, in terms of opening up. The first meeting can be considered as a metaphorical game of mirrors in which each presents itself as prevailing over the other forms of knowledge - one as the science of theory, the other as a science of techniques. This ordered and oriented posturing will collapse at the same time as the disappearance of a finite cosmos. In this dissolution, architecture and philosophy have recomposed themselves to deal with the space and time of inhabited milieus that affect not only the constitution of the gaze, but also a transformation of the world. It is examined how their interface is a heuristic structure of questioning.

Chris Younès

Ecole Nationale Supérieure d'Architecture de Paris-la-Villette
KEY WORDS

PHILOSOPHY

ARCHITECTURE

LIMITS

PASSAGES

METAMORPHOSIS 
It is well known that Jacques Derrida emphasized the idea of an essential cohabitation between philosophy and architecture, declaring: "The Collège international de philosophie should provide the place for a meeting (rencontre), a thinking meeting, between philosophy and architecture. Not in order to finally have them confront each other, but to think what has always maintained them together in the most essential cohabitations."

This paper addresses in particular a hypothesis about the metamorphoses of this meeting that, from unity of architectonics and principles, becomes multiple and of another nature. So there is a reevaluation in terms of limits and passages; in other words in terms of opening up.

\section{SYSTEMATICITY AND PSYCHE}

From Aristotle to Kant, philosophy has used architecture as a mirror of itself architectonically (Kant defined it as the "art of systems"); in its capacity to refer back to a means of organizing knowledge, each in relation to the others ${ }^{2}$. And architecture is reflected in philosophy, rediscovering the very essence of its foundations as set out by Vitruvius in terms of firmitas, utilitas and venustas. This first kind of meeting can also be considered as a metaphorical game of mirrors in which each presents itself as prevailing over the other forms of knowledge - one as the science of theory, the other as a science of techniques. It is the 'systematicity' of the approach in these two disciplines that characterizes this first liaison in which each one considered to a certain manner that it dominated the other forms of knowledge ${ }^{3}$.

This posturing will collapse at the same time as the disappearance of an ordered and oriented, finite $\operatorname{cosmos}^{4}$. In this dissolution, neither architecture nor philosophy could continue to consider themselves as being positioned at the summit; rather they were obliged to recompose themselves to deal with the space and the time of inhabited milieus. And in a way, they are obliged to deal with these dangerous liaisons.

MULTIPLICITY OF MEETINGS:

THE ISSUE OF LIMITS AND PASSAGES

After a certain "eclipse," to use Hubert Damisch's expression, running from Nietzsche to the $1980 \mathrm{~s}^{5}$, there was an explosion of sorts of meetings between architecture and philosophy marked by strong differences between authors and currents of thought. Some distanced themselves, others looked for forms of fusion. The proximity of certain philosophers of architecture was able to 
go quite far, as demonstrated by the famous collaboration between Derrida and Peter Eisenman with Bernard Tschumi in the conception of a folie for the park of La Villette in Paris. A collaboration that wasn not renewed. In fact, it is the whole relation between architecture and philosophy that found itself in a kind of deconstruction by a multiplicity of positioning; all about language one could say. Rethinking this meeting is an immense job and, in France, the research laboratory Gerphau and the international network PhilAU (philosophy, architecture, urban) I am in charge of, are attempting to contribute by highlighting issues related to limits and passages between these disciplines. But the words of limits and passages have to be questioned. These terms are directly associated. The word limit is "borrowed from Latin limes, limitis, a lane bordering a domain, a path between two fields, a limit, a border." It refers to the fringes, those of the knowable and unknowable, of finite and infinite, of order and chaos, of permanency and instability, human and non-human, life and death. Henri Maldiney highlights its proximity to the word 'passage' (derived from late Latin passare: "to pass," "to traverse"): "Traversing responds to this Indo-European root per, à travers, and the word experience, such as the Greek expeira and of a number of words derived from German. The Greek poros that means 'passage' signifies both a path and a ford, which enables passing from here to there, through the line or this zone of union and separation that fundamentally defines the most primitive of human situations."

Kant distinguished the concept of limits from that of bounds ${ }^{8}$.Both limits and bounds are borders, but the difference between the two is the following: bounds are negative borders (negations, as he calls them), while limits are positive ones. The distinctions, the mediations or the crossovers, all operate there, whether it is a question of between here or there, between what is permitted and what is prohibited, between what is desired and what is not. They designate everything there where one thing stops and another begins (Heidegger). Which means that limits are very paradoxical: in the same movement, sometimes separate, distinguish and sometimes create relations, revealing themselves to be surpassed and transgressed. In any way, limits are places of transformation and meeting. Certain voices mark themselves, for example that of Michel Serres, who insists that passages and links establish relations between the new scientific practices and the domains of the fluctuating and the composite and the hybridization. It is a matter of considering the fields and disciplines as "a continuum that is the berth of movements and exchanges: methods, models, results circulate everywhere on its bosom, exported or imported, anywhere and everywhere... The new scientific spirit develops into a philosophy of transport: intersection, intervention, interception... In other words, the division has less 
importance than the circulation along the paths or fibers, the circumscription of a region is of less interest than the knots, the crossroads created by the confluence of lines, knots that are, according to the thesis, themselves regions. In this new space, invention develops according to an ars inter veniendi; the intersection is heuristic, and progress is intertwining; this way there is an awareness of the complexity." In the development of the sciences, disciplinary rigor and specialization proved fruitful in delimiting the domains, the objects of study required to determine a given form of knowledge and to avoid its dissolution - a preliminary requirement in order to envisage meetings with other disciplines, but the 'transdisciplines' and 'indisciplines' are also going to multiply, seeking other forms of relationship. Derrida calls upon a 'limitrophy,' rethinking the potentialities of the culture of limit: "It isn't about what grows and increases to the limit, but that which nourishes the limit, generates it, raises and complicates it. Everything that I would say definitely doesn't consist in erasing limit, but rather multiplies its figures, complicates, thickens, delimits, folds, divides the line while making it grow and multiply." ${ }^{10}$ It helps to think about the issue of limits and passages between inside and outside, public and private, human and non-human.

\section{RESONANCES}

The new meetings between architecture and philosophy share common ground, exploring resonances and connections between space and thought, space and concept, concepts and affects, but also in regards to the event that appears suddenly.

"That which requires space, which calls it and desires it, is nothing other than that which is, by definition, without space - that is thought itself," 11 explains Jean-Luc Nancy in the preface of the important work La dislocation, by the French philosopher Benoit Goetz. We are invited by him, not only to think philosophy starting from architecture ${ }^{12}$ but to think about the concept of dislocation, and to take it seriously not only as an experience but as the condition of all experience. Rejecting all technical or semiological reduction of architecture, but exploring the ontological, physical, political, ethical, esthetical and poetic dimensions of inhabitation. The concept of dislocation expresses the tension developed between architecture and existence, signifying both the ontological dispersion inherent in all human existence and the power of the creation of spatiality. In Genesis, Adam and Eve vanquished from paradise were confronted with the first dislocation that is to say division of space. Another stage was the 'decosmization' of the world that divided "the terrestrial and celestial organization of places." In fact, the dis-location is 
defined not only as the interactions between places, but also as their raising questions in relation to the dislocation itself. In this argument, architecture is thought as an esthetical and "ethical substance" that constructs seamarks where man is held and maintained, reacting and working at a pre-symbolic level: "before constructing in order to be housed and make its lodging comfortable, humanity constructs in order to explain itself with space and invent for itself a posture and continuity," writes Benoît Goetz, whether through building architecture-monuments or architecture-events but even more likely everyday architecture. Refusing the generalities and simplifications as the disciplinary compartmentalization, the challenge is to continue the capacity of Opening up, of perpetual departure; as it was with the deconstruction movement. About meeting of architecture and philosophy, or literature, it means to transcend the disciplines to explore another situation that goes beyond the stage of analogies like that of the juxtaposition of constructed knowledge in specialized sciences or domains.

As such architecture and philosophy interpenetrate and question each other not in a relation of surveillance, or the illustration of one field in regards to another, but in dynamic and uneasy relations. Strongly renewed by the imperative interfaces with the urban, the countryside, the territory, the environment, the landscape that have become constitutive dimensions, the constellation engendered by architecture leads to a rethinking of the productions at work. The convocation of knowledge theory and practice in the domains that affect not only the constitution of the vision and the expression of a thought but a transformation of the world, take us back to the conditions of dwelling in contemporary civilization. New challenges for regenerations and metamorphoses of the inhabited milieus are at stake. The value of the coexistence of cultures among themselves and the coexistence of culture and nature raises even more questions, so that for the first time in the history of humanity neither architecture, nor the city, can refer to an initial foundation. In their meeting, architecture and philosophy think what each is responsible for. It means what they are in charge of. Even while these models are in crisis, they acutely pose the problem of the impact of ethical and political choices. Architecture and philosophy are challenged to think and invent how logos, topos, aisthesis, are interlaced, given that all spatial-temporal experience implies a concrete manner to be somewhere in a rhythmic opening. It appears clearly that the meeting of architecture and philosophy may become a heuristic meeting as a structure for questioning the doing. The limitrophy, as addressed by Derrida, is a very stimulating way of thinking the limits and passages between thinking and doing. "With limitrophy, we are undoubtedly in a zone 
of resonance between architecture and philosophy. "Another logic of the limit' could open up in a zone of fertile meetings between writers and artists, architects and philosophers." 13

One can say that the relationship of philosophy with architecture is not easy but architecture has the power to solicit the philosophy in the sense as reminded by Derrida "sollicitare signifies in old French to shake as in making everything tremble in totality". ${ }^{14}$ 
Jacques Derrida, 'Point de folie - maintenant l'architecture", in Psyché. Inventions de l'autre (Paris: Galilée, 1987).

Daniel Payot, Le philosophe et l'architecte. Sur quelques déterminations philosophiques de l'idée d'architecture (Paris: Aubier-Montaigne, 1982).

3 In the 'systematicity' of Hegel, architecture is positioned at the beginning of the dialectical saga of the absolute spirit.

4

5

Alexandre Koyré, Du monde clos à l'univers infini (1957) (Paris: Gallimard, 2003).

Hubert Damish, 'L'éclipse', in Temps de la réflexion n¹ (Paris: Gallimard, 1980).

Dictionnaire historique de la langue française, A. Rey (dir.)

'A l'écoute de Henri Maldiney"' in C. Younès, Ph. Nys et M. Mangematin (codir.), L'architecture au corps (Bruxelles: Ousia, 1997), p.13.

Immanuel Kant, Prolégomènes à toute métaphysique future qui pourra se présenter comme science (1783), trans. L. Guillermit (Paris: Vrin, 1996).

M. Serres, 'L'interférence", in Hermès II (Paris: éditions de Minuit, 1972), p.10 and p.13.

Jacques Derrida, L'animal que donc je suis (Paris: Galilée, 2006).

Jean-Luc Nancy, preface of La dislocation, by Benoît Goetz (Paris: Verdier, 2001).

Benoît Goetz, La dislocation.

Benoît Goetz, Théorie des maisons (Paris: Verdier, 2011).

Société française de philosophie, 25 janvier 1968. 
Goetz, Benoît. Théorie des maisons. Paris: Verdier, 2011.

Damish, Hubert . "L'éclipse.” In Temps de la réflexion n¹. Paris: Gallimard, 1980.

Derrida, Jacques. 'Point de folie - maintenant l'architecture." In Psyché. Inventions de l'autre. Paris: Galilée, 1987.

Derrida, Jacques. L'animal que donc je suis. Paris: Galilée, 2006.

Kant, Immanuel. Prolégomènes à toute métaphysique future qui pourra se présenter comme science (1783), trans. L. Guillermit. Paris: Vrin, 1996.

Koyré, Alexandre. Du monde clos à l'univers infini (1957). Paris: Gallimard, 2003.

Nancy, Jean-Luc. Preface of La dislocation, by Benoît Goetz. Paris: Verdier, 2001.

Payot, Daniel. Le philosophe et l'architecte. Sur quelques déterminations philosophiques de l'idée d'architecture. Paris: Aubier-Montaigne, 1982.

Serres, M. ' 'L'interférence.” In Hermès II. Paris: Editions de Minuit, 1972. 
JEVREJSKI ZID:

Ajzenmanovo carstvo

\section{Renato Rizzi}

U ovom radu, autor se zalaže da i arhitektura, kao i druge estetske discipline, već dugo ukazije na prvobitni problem: osećaj forme. Forma se smatra mnoštvom ekspresivnih jezika koji potiču od određene vrste znanja. Arhitektura je viđena kao rad realizacije, saznanje znanja, a forma je prezentacija, suština je u osećaju.

Autor tvrdi da je više promenljiv, mada ne jedini među četiri faktora, pravo na znanje. Ako se više ili manje proširi i produbi, veća je ili manja naša sposobnost da klizimo duž osnovne linije. Ili ka "sadržaju istine jednog dela", prema rečima Valtera Benjamina. Pretpostavka, iako tek treba da se dokaže, nameće logiku mišljenja kojoj treba pridružiti estetiku mišljenja: poklon sastavljanja, slika jedinstva celine.

U nekoliko delova, preko teoloških pitanja, scena mišljenja, tumačenja o zastupanju i razmišljanju, ideja, koncepata i fenomena, autor diskutuje o mogućim tumačenjima rada Pitera Ajzenmana.

KLJUČNE REČI: TELOS, IKONOLOGIJA, EPISTEMOLOŠKA PREMISA, FORMA, INTERPRETACIJA, TEOLOGIJA, JEVREJSKA PARADIGMA, GRČKO-HRIŠĆANSKA PARADIGMA

ARHITEKTURA I FILOZOFIJA:

Paradoksi i metamorfoze njihovog sastanka

\section{Chris Younès}

Poznato je da je Žak Derida (Jacques Derrida) istakao ideju suštinskog suživota između filozofije i arhitekture, izjavljujući: „Collège inetrnational de philosophie bi trebalo da obezbedi mesto za sastanke (recontre), sastanak razmišljanja, između filozofije i arhitekture. Ne da bi se konačno sukobljavale, već da se razmišlja o onome što ih je oduvek održavalo zajedno u najsuštinskijem suživotu." Ovaj rad se posebno bavi hipotezom o metamorfozi ovog sastanka da, od jedinstva arhitektonike i principa, postaje mnogostrukost i drugog karaktera. Tako da je tu preispitivanje u smislu granica i prolaza; drugim rečima, u smislu otvaranja. Prvi sastanak se može smatrati kao metaforička igra ogledala u kojoj svako predstavlja sebe kao prevlađujući u odnosu na druge oblike znanja - jedan kao nauke o teoriji, drugi kao nauke o tehnikama. Ovo uređeno i orijentisano poziranje će propasti u isto vreme sa nestankom konačnog kosmosa. U tom raspadu, arhitektura i filozofija su se 
prekomponovale da bi se bavile prostorom i vremenom naseljenih sredina koje utiču ne samo na konstituciju pogleda, već isto tako na transformaciju sveta. Istražuje se kako je njihov interfejs heuristička struktura ispitivanja.

KLJUČNE REČI: FILOZOFIJA, ARHITEKTURA, GRANICE, PROLAZI, METAMORFOZA

\section{MARGINE ARHITEKTURE}

\section{Maurizio Ferraris}

Polazeći od primera naročito ružne Palazzo Nuovo u Torinu, ovaj rad ima za cilj da predstavi, putem poređenja između arhitekture i vizuelnih umetnosti, deset interpretacija (konceptualnost, auralnost, suplementarnost, neodgovornost, pareregonalnost, autorijalnost, podređenost, dokumentalnost, piramidalnost, stvarnost), koje opisuju karakteristike savremene arhitekture kao što i ukazuju na određene granice i pravila sa kojima arhitektura mora da se pomiri.

KLJUČNE REČI: ARHITEKTURA, FILOZOFIJA, VIZUELNE UMETNOSTI,

DOKUMENTALNOST,STVARNOST, DERIDA, ESTETIKA

ZAKON OIKOSA.

Žak Derida i Dekonstrukcija Stanovanja

\section{Francesco Vitale}

Ovaj rad skicira bitne linije rada koji je u toku a koji ima za cilj da prati putanju koju je otviro Derida ka dekonstrukciji stanovanja. Nameravam da pokažem kako je Deridina briga za arhitekturu strogo povezna sa urgentnošću dekonstrukcije stanovanja koja naseljava njegov rad od najmanje Platonove Farmacije (1966), pa nadalje. Prema Deridi, i filozofija i arhitektura su podređene arhaičnoj koncepciji stanovanja koja još uvek opseda naš način razmišljanja i izgradnje mesta stanovanja (teritorija, grad, kuća) i, na taj način, utiče na političku dimenziju našeg života.

KLJUČNE REČI: STANOVANJE, DEKONSTRUKCIJA, KHORA, ONTO-TOPO-POLITIKA, PROSTOR

\section{LA NAVE DI PIETRA/ KAMENI BROD}

\section{Zoran Lazović:}

Svet se stalno gradi i razgrađuje. Da li postoji suštinski paradoks dekonstruktivizma u kreativnim radovima arhitekata? Čemu odgovara arhitektonski projekat? Dnevnik priče u kojoj je pripovedač svoj sopstveni tumač:Od neizvesnog prisećanja i izbledelih kopija do višestrukih novih 
originala. Gde je bio Vavilon arhitekte? Grupni portret. Kriegs Insel in Plannen, Isključenje iz zemaljskog Raja. Blok 24. Kulturni centar Tré́eg Milenijuma. Futuristički pristup Savskom amfiteatru Tré́eg Milenijuma. Urbana Utopija: Omaž gradu Vukovaru. Grad Nade. Cauchemare - košmar. Noćni rad. Imago mundi. Opservatorija budućnosti? Lutanje i život na niskoj frekvenciji. Beogradska Nekroza i Smrt Srbije. Paralela introspekcije, ili smrt mnogih svetova pred nama. Oni koji ne mogu da vide da će umiranje videti neke druge svetove kako nestaju: njihovo propadanje, rastavljanje, nestanak. Pogled u ambis prošlosti: radi nekog traga, ili radi nešto više tragova uporedno. Arhitektura. Slike. Fragmenti. Hibridi. Svedočenje očuvanih slika, objekata, arhitektonskih kompozicija, ikonografskih fragmenata, montaža, sklopova, umetničkih kolaža, mentol brikolaža. Odraz velikih događaja i ideja: neprekidno menjajujući i nestajući Kontekst. Kontekst velikih pokreta. Moda. Trendovi.Glavne tendencije. Ratovi. Kreativni prioriteti i vizije. Lekcija iz anatomije: sučavanje sa sopstvenim projektima i konstruktima, vezivanje, analiza, dekonstrukcija, reminiscencija i rekonstrukcija, se-ćanje (ponovno vraćanje delova celine). Neki trag već uništenog postojanja i neizbežnog nestajanja. Da li postoji iščekivanje i predviđanje događaja i raspadanje, odlazak i povratak? Kakvi su to ramovi imali slike koje su bile nevidljive u to vreme? Pratiti trag kroz Spektar Deride.

KLJUČNE REČI: ARHITEKTURA, IDEJE, KONCEPTI, KONTEKSTI, DEKONSTRUKCIJE, DESTRUKCIJE, RETROSPEKTIVA 